DOI: $10.17516 / 1997-1370-0869$

УДК 339

\title{
Agent-Based Modeling of Spatial Economic Systems: a Review
}

\author{
Alexander A. Tsyplakov, Larisa V. Melnikova \\ and Naimdjon I. Ibragimov* \\ Novosibirsk State University \\ Novosibirsk, Russian Federation
}

Received 02.08.2021, received in revised form 15.09.2021, accepted 10.11.2021

\begin{abstract}
The paper describes the current state of agent-based modeling of geographical space and spatial economic systems. We explore reasons why this approach to modeling spatial phenomena is of particular interest. Agent-based models (ABMs) allow accounting for agents' spatial heterogeneity, the existing structure of the space, locality of interactions between agents. A survey of approaches to introducing space into the models and examples of the existing spatial models is presented. There is a great variety of spatial ABMs, but they relate predominantly to the local and city level, rather than to the economy as a whole. Spatial ABMs at the level of large regions and countries are not yet sufficiently developed, but have good prospects in the future. With increasing availability of geodata and technological development in general the number of applications and coverage of spatial ABM will grow.
\end{abstract}

Keywords: agent-based modeling, spatial analysis, economic space.

The reported study was funded by RFBR, project number 20-110-50606.

Research area: economics.

Citation: Tsyplakov, A.A., Melnikova, L.V., Ibragimov, N.I. (2021). Agent-based modeling of spatial economic systems: a review. J. Sib. Fed. Univ. Humanit. soc. sci., 14(12), 1910-1919. DOI: $10.17516 / 1997-1370-0869$

(C) Siberian Federal University. All rights reserved

* Corresponding author E-mail address: alexander.tsyplakov@gmail.com; larisa.svet.victorovna@gmail.com; naimdjon.ibragimov@gmail.com

ORCID: ORCID: 0000-0002-9297-3269 (Tsyplakov); 0000-0001-7427-7289 (Melnikova); 0000-0001-8540-5039 (Ibragimov) 


\title{
Агент-ориентированное моделирование пространственных экономических систем: обзор
}

\author{
А. А.Цыплаков, Л. В. Мельникова, Н. И. Ибрагимов \\ Новосибирский государственньй университет \\ Российская Федерачия, Новосибирск
}

\begin{abstract}
Аннотация. В статье описывается современное состояние агент-ориентированного моделирования географического пространства и пространственных экономических систем. Раскрываются причины, по которым данный подход к моделированию пространственных явлений представляет особый интерес. Дан обзор подходов к учету пространства в моделях и приведены примеры существующих пространственных моделей. Делается вывод о том, что пространственные агенториентированные модели на уровне экономик больших регионов и стран пока недостаточно развиты, но обладают в будущем хорошими перспективами.
\end{abstract}

Ключевые слова: агент-ориентированное моделирование, пространственный анализ, экономическое пространство.

Представленное исследование поддержано грантом РФФИ, проект № 20-110-50606.

Научная специальность: 08.00.00 - экономические науки.

\section{Introduction}

Uneven distribution of economic activity across geographical space is typical for every national economy. The phenomenon is especially important for the countries with vast territory and diverse geography. Therefore, it is desirable to explicitly account for the spatial factor in modeling and forecasting such economies (in particular, the Russian economy). There are many various theoretical and applied economic models and methods explicitly including space. In particular, spatial aspects are considered in the firm location theory, spatial competition models and land use models. However, the task of adequate space representation at the national economy level remains to be largely unresolved problem. For instance, the majority of macroeconomic multiregional models represent spatial aspects only indirectly and in a generalized manner, without explicitly using geographical coordinates, distances, etc.

Agent-based modeling opens good prospects for introducing geographical space into macroeconomic models. An agent-based model (ABM) simulates interactions between multi- ple computer agents, where each agent can be equipped by its own properties and behaviors. In the past decades agent-based modeling as a special kind of simulation progressed from isolated pilot studies $[1,2]$ to large-scale applied models such as Eurace@UNIBI [3] and LAGOM RegIO [4].

Problems of modeling space in ABMs are discussed in both special reviews $[5 ; 6 ; 7]$ and narrower topical ABM reviews regarding land use [8], urban systems [9] and choice of residence [10]; transport planning [11] and logistics [12]; ecology [13] and environmental economics [14]; networks [15]; marketing [16]; and sociology [17]. Critical reviews consider the prospects of socio-ecological ABMs [18] and geographical ABMs [19].

Our review of the current state of spatial agent modeling focuses on simulating econom$i c$ spatial systems, since the authors are involved in developing an ABM of the Russian economy [20, 21]. Section 2 analyses characteristics of agent-based models and model agents that give advantages in modeling spatial processes. Section 3 discusses approaches to representing 
space in ABM. Section 4 describes several spatially-explicit ABMs. We use the term "space" here only in the geographical sense.

\section{Agents and agent-based modeling}

Agent-based models (ABMs) is a relatively new and rapidly developing area of applied modeling. The essence of ABMs is simulation of autonomous agents and their environment inside which they reside and interact according to certain rules. The models of this class are implemented through computer experiments and they typically include dynamics and randomness. By changing parameters and scenarios one can forecast the behavior of the analyzed system under various conditions. Unlike other simulation models, ABMs are built from the micro to the macro level $[22,23]$.

Agent-based models is a viable substitute for analytical models, which are typically based on a number of simplifying assumptions devaluing their apparent generality compared to computer simulations (agent rationality, complete information, existence of a representative agent, homogeneity of agents and the environment, symmetry, and so on). More importantly, using ABMs is a promising alternative to the standard equilibrium approach, applicability of which to many real-life phenomena is rather questionable [23].

The following definition of an agent is established in the literature: it is an entity within some environment that possesses autonomy with respect to this environment and other agents. An agent is described by a state that changes over time. It can perceive the environment and can be influenced by it. An agent can act and can influence the environment through this activity, pursuing a certain goal or following its own rules of behavior $[24,25$, p. 6,26 , 27]. Space should be considered as a constituent of the environment. In a spatial ABM the state of an agent should include a binding to some areas of space.

Analysis of the views of different authors on general properties of agents and agent-based models allows to identify those, which are the most important for spatial modeling [2, p. 37, 25 , pp. $5-6,28,29,26,30$, p. $235,27,23,17$, $31,32]$.
First, ABMs are well suited to reflecting agent heterogeneity since every agent is unique, possessing specific attributes and a state. Thus, in an ABM one can bind agents to different locations.

Second, ABMs provide natural description of actual economic and social systems, because they can reflect the organization of autonomous agents inside a complex-structured environment and the constraints they face in it. Agent behavior and inter-agent relations in spatial ABMs can be made contingent on location in order to account for the features and structure of the space.

Third, it is often assumed that each agent is local, interacting only with some limited subset of other agents and objects. This feature helps to implement the known geographical effect of distance decay.

Forth, an important ABM feature is the emergence of peculiar effects and structures at the macro level due to agents' activity at the micro level.

Fifth, ABMs allow studying rather complex systems which are hard to analyze theoretically. Introducing space complicates analytics significantly and thus spatial models usually have simplified formulations (an example are the models of new economic geography [33]). At the same time, ABMs have no principal issues here since spatial coordinates are just variables of an inner agent state.

One can agree with Betty et al. that ABMs are well suited for modeling spatial phenomena: "It is easy to see why the idea of agentbased modelling (ABM) has become so popular in the last two decades for it begets a style of modelling that has the capability of reflecting the richness of the world in a way that appears essential to any good explanation of how spatial structures such as cities, regions, the global system itself as well as all its physical components evolve and change." [34, p. 3].

\section{Taking account of space in ABMs}

The spatial aspect of a model reflects geometric and topological properties of this model and is associated with such concepts as proximity, distance, connectedness, orientation, coordinates, density, extent, etc. Space in an 
$\mathrm{ABM}$ is a part of the agent's environment. It can be defined as a system of areas with agents or other objects tied to these areas. Agents can be linked to several locations (e.g., home and work), and can be mobile. An important role is played by the relative location of model entities and the nature of the spatial relationships between them.

Depending on the models' purposes, space in them can be structured differently. It can be continuous or discrete (e.g., a grid). Network structure (nodes with connecting arcs) or geometric space (1D, 2D or 3D) can be used.

Transport and information routes' structure interactions and movements. (The absence of) routes can impose locality and constrain connectivity. For instance, mobility and interactions in the simplest models are often localized in adjacent nodes.

Space structure can change over time in dynamic spatial models. For example, if a model includes roads creation, new roads can change the patterns of interactions between agents or their mobility.

At the stage of ABM initialization, the environment, agents and other model entities are created. At that stage spatial agents of economic ABMs (people, firms and resources) are given their locations.

Models are often staged in artificially designed spaces. When some actual terrain is modeled, one can rely both on available data and on plausible artificially created data $[35$, 36]. Sources can be quite diverse: maps, sampling surveys, government regional statistics, etc. [37].

Agents' activity should be governed by special algorithms and rules of spatial choice. Such choice can be purely random or determined by agent properties. Of the most interest here is the choice between alternatives (an object for interaction, a route, etc.) on the basis of a certain target criterion like spatial proximity criterion that reflects the "friction of distance" phenomenon. For instance, in many $\mathrm{ABMs}$ agents prefer the shortest route.

In economic $\mathrm{ABMs}$ agents can take into account proximity, costs, benefits or attractiveness of the spatial alternatives $[38,39,40]$. For example, when selecting a job, a worker agent may consider the wage size and transport accessibility. Land prices, tax rates, natural and labor resources may influence firm location. Route selection may depend on transport expenses and time costs.

Overall, spatial choice algorithms at the agent level determine the spatial structure of macro indicators. If spatial statistics on the modeled system is available, it can be used to calibrate and verify an ABM. Calibration is carried out by choosing model parameters that ensure good conformity with the actual spatial proportions.

\section{The existing spatial ABM}

Spatial agent modeling has a rather long history. Back in the mid-20 century a Swedish geographer Torsten Hägerstrand [1] proposed models of innovation diffusion that anticipated some ideas of spatial ABMs, such as representing space with agent-populated cells ("cellular automaton", CA), model calibration and verification. Innovations in these models are transferred via personal contact. Transfer probabilities are influenced by geographical anisotropy and decrease with distance thus introducing "friction of distance" in innovation propagation.

After placing agents into cells, a researcher would be tempted to move them. Unsurprisingly, early spatial models, mostly of CA form (see [41, ch. 4]), were aimed at studying agent migration. Early models developed independently by Sakoda and Schelling simulate placement of residents in a settlement using chips of two colors put on a checkerboard. Agent migration is induced by dissatisfaction with the composition of the residents in adjacent cells [42, 2]. In a family of Sugarscape spatial ABMs cells of a $2 \mathrm{D}$ grid contain resources. Agents consume resources and move across cells. They can also propagate, die, pollute the environment, transfer culture, trade resources, fight, etc. [22].

In the domains where explicit spatial representation is important, such as transport planning $[43,44]$ or urban land use [35], space in $\mathrm{ABMs}$ has become more complex, reflecting the actual terrain in greater detail. For instance, in a model of land use on the Australian coast [45], agents are represented by polygonal plots 
and are involved in trading the rights for polluting water resources.

Modeling retail trade required representation of particular geographical areas. Space in a fuel sales model [46] corresponds to the West Yorkshire area where households and competing petrol stations are located. The model on retail demand in Leeds [47] is built on the data about transactions made with the loyalty cards of a British grocery retailer, which allowed simulating the choice of stores by buyers in space and time. Another ABM of a retailer operates in the space of the Zurich municipal region [48]. It simulates store location decisions taking into account land prices.

In urban models space inevitably becomes fully geographical. CABMUD, a comprehensive agent-based model of social-and-economic development of Moscow [36] uses a GIS representation with several layers (districts, roads, population, etc.). Simulating housing markets also requires binding agents to actual locations. E.g., RHEA [39] reproduced housing market in small coastal towns. Here space is represented by parcels initialized from GIS data. Household agents have utility functions depending on housing services, coastal amenities of the parcel, the risk of flood and the size of disposable income after paying residential rent and transport costs. The emphasis is on economic microfoundations, endogenous emergence of land prices and their spatial distribution.

Developing ABMs with the necessary set of macroeconomic variables and interactions usually compel researchers to sacrifice space detail. In the "center-periphery" model [38] following the lines of new economic geography (NEG) agents act in an abstract space of several town-points. The model features "iceberg" transport costs and increasing returns typical for NEG. Unlike NEG models, it does not explicitly rely on the equilibrium approach: a state resembling the equilibrium can develop as a result of adaptive agent behavior.

The spatial resolution would depend on the research topic, the scale of the phenomenon under study and data availability. The models in land use, transport systems and geo-marketing explore urban and rural terrain. At the same time, analysis of spatial proportions of the economy and inter-regional inequality should explore the level of sub-national territorial units (regions).

Evidently the agent-based approach is capable of dealing with inter-regional level. However, despite this obvious potential not many ABMs cover space of a single or several countries or regions. The most influential are the macroeconomic models belonging to the Eurace, CATS, K+S, JAMEL, LAGOM families described in [49]. Typically, such models are first developed in a point formulation and obtain spatial versions only afterwards in the course of their further development.

Multi-regional and multi-country ABMs are represented by Eurace@Unibi, LAGOM Regio; Eurace Open, AB-SFC and K+S. Their main characteristics are summarized in Table 1. Usually, such models include firms producing consumer and capital goods, further on referred to by prefixes $\mathrm{C}$ - and $\mathrm{K}$-.

Eurace@Unibi is developed as a universal tool for macroeconomic analysis in the regional context and experiments with economic policy $[3,50]$. Regions can differ in terms of the population size, quality of human and production capital. Firms and workers are located in particular regions. Workers can commute to the neighboring region, but transport costs restrict such a possibility.

Markets operate under different spatial scales. Capital and financial markets are common for all regions. Supply on the market of $\mathrm{C}$-goods is shaped globally across regions, while demand is localized at regional trading facilities - malls. If the actual demand exceeds the expected one, malls cannot fully satisfy it. Thus, spatial localization can reduce market efficiency. In the labor market, on the contrary, demand is shaped globally, but "efficient supply" of labor turns out to be local due to the impeding influence of travel costs. Thus, "friction of distance" hampering adaptation and market clearing is modeled. Greater firm productivity in one region leads to greater labor demand, increased wages and inflow of workers from another region.

LAGOM Regio [4] is aimed at simulation of economic growth of interacting regions. The model is populated with firms from five sec- 
Table 1. Spatial models of the economy

\begin{tabular}{|c|c|c|c|c|c|c|}
\hline Model & $\begin{array}{c}\text { Eurace@ } \\
\text { UNIBI }\end{array}$ & $\begin{array}{l}\text { LAGOM } \\
\text { Regio }\end{array}$ & Eurace Open & AB-SFC & $\mathrm{K}+\mathrm{S}$ & PolicySpace \\
\hline Division & 2 regions & $\begin{array}{l}5 \text { regions } \\
\text { representing } \\
\text { Germany and } \\
\text { European } \\
\text { macro-regions }\end{array}$ & countries & $\begin{array}{l}\text { countries, } \\
\text { representing } \\
\text { regions of } \\
\text { Europe }\end{array}$ & countries & $\begin{array}{c}46 \text { PCAs and } \\
333 \mathrm{mu}- \\
\text { nicipalities } \\
\text { in Brazil }\end{array}$ \\
\hline $\begin{array}{c}\text { Mobility and } \\
\text { barriers }\end{array}$ & $\begin{array}{l}\text { firms: } \mathrm{n} \\
\text { labor: } \mathrm{t} \\
\text { goods: } \mathrm{m} \\
\text { finance: } \mathrm{m}\end{array}$ & $\begin{array}{l}\text { goods: } m p \\
\text { firms: } n \\
\text { labor: } m \\
\text { finance: } m\end{array}$ & $\begin{array}{l}\text { goods: } \mathrm{m} / \mathrm{n} \\
\text { labor: } \mathrm{m} / \mathrm{n} \\
\text { finance: } \mathrm{m} / \mathrm{n} \\
\text { currency: } \\
\text { union }\end{array}$ & $\begin{array}{l}\text { goods: } \mathrm{m}+\mathrm{n} \\
\text { labor: } \mathrm{n} \\
\text { finance: } \mathrm{m} \\
\text { investment: } \mathrm{n} \\
\text { currency: } \\
\text { union }\end{array}$ & $\begin{array}{c}\text { goods: } n \\
\text { currency: } x r\end{array}$ & $\begin{array}{l}\text { goods: } m \\
\text { firms: } \mathrm{n} \\
\text { labor: } \mathrm{m}\end{array}$ \\
\hline $\begin{array}{l}\text { Difference be- } \\
\text { tween regions } \\
\text { (countries) }\end{array}$ & $\begin{array}{c}\text { population } \\
\text { size, workers } \\
\text { qualification, } \\
\text { technologies }\end{array}$ & $\begin{array}{l}\text { labor pro- } \\
\text { ductivity, } \\
\text { tax rates, } \\
\text { unemploy- } \\
\text { ment benefits }\end{array}$ & $\begin{array}{l}\text { technologies, } \\
\text { tax rates }\end{array}$ & $\begin{array}{l}\text { technologies, } \\
\text { tax rates }\end{array}$ & technologies & $\begin{array}{l}\text { size, life } \\
\text { quality }\end{array}$ \\
\hline Agents & $\begin{array}{c}\text { C- and } \\
\text { K-firms, } \\
\text { households, } \\
\text { local malls, } \\
\text { regional } \\
\text { governments }\end{array}$ & $\begin{array}{c}\text { firms in } \\
5 \text { sectors, } \\
\text { households, } \\
\text { regional } \\
\text { governments }\end{array}$ & $\begin{array}{c}\text { C-firms, } \\
\text { households, } \\
\text { banks, cen- } \\
\text { tral banks, } \\
\text { governments }\end{array}$ & $\begin{array}{l}\text { C-firms, } \\
\text { households, } \\
\text { banks, gov- } \\
\text { ernments }\end{array}$ & $\begin{array}{l}\text { C-firms, } \\
\text { K-sectors }\end{array}$ & $\begin{array}{c}\text { C-firms, } \\
\text { citizens, } \\
\text { municipalities }\end{array}$ \\
\hline $\begin{array}{c}\text { Modeled } \\
\text { phenomena }\end{array}$ & $\begin{array}{l}\text { convergence } \\
\text { and diver- } \\
\text { gence in } \\
\text { productivity } \\
\text { and income } \\
\text { distribution }\end{array}$ & $\begin{array}{l}\text { differences } \\
\text { in regional } \\
\text { trajectories of } \\
\text { endogenous } \\
\text { growth }\end{array}$ & $\begin{array}{l}\text { benefits from } \\
\text { integrating } \\
\text { countries into } \\
\text { a currency } \\
\text { union }\end{array}$ & $\begin{array}{l}\text { long-term } \\
\text { dynamics } \\
\text { in a curren- } \\
\text { cy union }\end{array}$ & $\begin{array}{l}\text { growth of in- } \\
\text { terdependent } \\
\text { economies, } \\
\text { divergence } \\
\text { and polar- } \\
\text { ization } \\
\end{array}$ & $\begin{array}{l}\text { population } \\
\text { migration } \\
\text { and differ- } \\
\text { entiation of } \\
\text { regions by the } \\
\text { quality of life }\end{array}$ \\
\hline $\begin{array}{l}\text { Policy } \\
\text { analysis }\end{array}$ & $\begin{array}{l}\text { fiscal policy, } \\
\text { leveling } \\
\text { through } \\
\text { investments } \\
\text { in technol- } \\
\text { ogies and } \\
\text { human capital }\end{array}$ & climate policy & $\begin{array}{l}\text { monetary and } \\
\text { fiscal policy, } \\
\text { in a curren- } \\
\text { cy union }\end{array}$ & $\begin{array}{c}\text { different } \\
\text { fiscal regimes } \\
\text { in a curren- } \\
\text { cy union }\end{array}$ & - & $\begin{array}{l}\text { efficiency of } \\
\text { spatial divi- } \\
\text { sion in terms } \\
\text { of producing } \\
\text { public goods }\end{array}$ \\
\hline
\end{tabular}

Notation: $\mathrm{m}$ - mobile, $\mathrm{n}$ - non-mobile, $\mathrm{m} / \mathrm{n}$ - mobile or non-mobile depending on the model version, $\mathrm{m}+\mathrm{n}-$ partly mobile, partly not, $\mathrm{mp}$ - mobile with lower probability, $\mathrm{t}$ - mobile with transport costs, $\mathrm{xr}$ - changing exchange rate.

tors, households, foreign trade agents, regional governments; there is also a common financial system. Besides $\mathrm{C}$ - and $\mathrm{K}$-sectors, there is an intermediary goods sector. $\mathrm{CO}_{2}$ emissions are a by-product of the energy firms.

The firms are immobile, while households can migrate. "Friction of distance" shows itself through a higher probability on a commodity and labor market to choose a partner from the agent's home region. Thus, space emerges as a network of contacts. This mechanism leads to locality of interactions between agents. However, this is not permanent due to the limited memory.

Eurace Open is a multi-country development of Eurace [51]. The model implements a flexible scheme of inter-country connectivity: countries may form clusters with some markets (commodity, labor, financial) being common. In the basic configuration two countries form a 
full-fledged union while two others are isolated and used for comparisons.

In AB-SFC model (SFC stands stock-flow-consistent), different markets have different degrees of connections in a fully multi-country setting [52]. Labor, in particular, does not move between countries, while the loan market is common. C-goods are divided into "traded" and "non-traded". This model takes account of distance, but the space is not geographical (it is a space of characteristics reflecting product differentiation).

A group of dynamic models $\mathbf{K}+\mathbf{S}$ (Keynes + Schumpeter) also has a multi-country version [53]. The model combines the Schumpeterian economic growth with the Keynesian role of demand. Firms compete on international markets under the conditions of endogenous specialization, which is the result of accumulating technological knowledge. Space of technologies and a distance in this space are used to model technological imitation; however, geographical space is absent.

These macroeconomic ABMs are similar because spatially regions or countries represent points. Only Eurace@Unibi is an exception here. However, space detailing is rather weak even in this model. Countries or regions in such models are separated with borders and, depending on the model setting, mobility of particular goods or resources between two different countries can be full, partial or non-existent.

The PolicySpace model of a region in a country (PCA, population concentration area) [40] has an intermediate position between urban and macroeconomic models. Agents are municipalities, firms and citizens organized into families. Municipalities have geographical shapes, families occupy houses, firms and houses are characterized by geographical coordinates, i.e., the model is spatially explicit. Families can migrate, which brings spatial dynamics into the model. Three markets operate in the model: C-goods, real estate and labor. Municipalities collect taxes and invest into quality of life in their territories (however, the policy of leveling the quality of life across regions may take place).

Explicit distance calculation links all three markets spatially in the model. Firms choose workers based on their qualification or the distance to their residence. Families choose goods on the market based on their prices or the distance to firms. The criteria are chosen stochastically. If a worker loses (also stochastically) or finds a job, the family income also changes and it looks for a new residence. Due to migration distances change and influence decisions on buying goods and hiring workers. House price depends on its size and the local quality of life. Quality of life depends on the government spending and is subject to change. As a result, prices in municipalities change, which influences decisions to move, while changes in the size of the population influence consumption and hiring decisions, and further the value of the local quality of life index. Thus, all markets are interrelated in space.

\section{Conclusion}

The prospects of agent modeling for describing spatial phenomena are based on a possibility to take into account spatial heterogeneity of agents and the existing spatial structure, locality of interactions between agents.

Currently, the models describing local and urban levels rather than the level of the economy as a whole dominate. Few macroeconomic AMBs feature rather elementary spatial aspect: regions or countries are divided by movement-hampering boundaries, but lack specific spatial positions.

At the same time, for the macroeconomic analysis of a country with a vast and unevenly developed territory, it is fundamentally important to use agent-based models with agents and resources distributed across explicit space. The authors of the article are involved in developing such a model for the Russian economy. This model, outlined in [20,21] and [49], is not covered in the review. In this three-regional 6-sector ABM, tied to the map of Russia, agents have geographical coordinates. Transport costs depend on distance and influence the buyer's choice of a seller, and, consequently, the geography of transport flows. The model is compatible with an existing normative model (an interregional "input-output" model) and is based on the actual data. 
In the future, applications of spatial ABMs and their coverage will continue expanding following growing geodata accessibility and technological advancement. With access to better and more detailed information and more powerful computational systems researchers shall be able to design virtual spatial economic systems and experiment with them to analyze the effects of regional policy and predict spatial proportions of the economy.

\section{References}

1. Hägerstrand, T. A Monte Carlo approach to diffusion. Archives Européennes de Sociologie, 1965, vol. 6, pp. 43-67. DOI: 10.1017/S0003975600001132.

2. Schelling, T.C. Dynamic models of segregation. Journal of Mathematical Sociology, 1971, vol. 1, pp. 143-186. DOI: 10.1080/0022250X.1971.9989794.

3. Dawid H., Harting P., Neugart M. Economic convergence: policy implications from a heterogeneous agent model. Journal of Economic Dynamics and Control, 2014, vol. 44, pp. 54-80. DOI: 10.1016/j. jedc.2014.04.004.

4. Wolf, S. et al. A multi-agent model of several economic regions. Environmental Modelling \& Software, 2013, vol. 44, pp. 25-43. DOI: 10.1016/j.envsoft.2012.12.012.

5. Ausloos, M., Dawid, H., Merlone, U. Spatial interactions in agent-based modeling. In: Commendatore P., Kayam S., Kubin I. (eds). Complexity and Geographical Economics, 2015. Dynamic Modeling and Econometrics in Economics and Finance, vol. 19. Springer, Cham, 353-377. DOI: 10.1007/978-3-31912805-4 14 .

6. Dibble C. Computational laboratories for spatial agent-based models. In: Tesfatsion, L., Judd, K.L. (eds.), Handbook of Computational Economics, 2006, vol. 2. North-Holland, Oxford, 1511-1548. DOI: 10.1016/S1574-0021(05)02031-9.

7. Stanilov, K. Space in agent-based models. In: A. Heppenstall, A.T. Crooks, L.M. See, \& M. Batty (Eds.), Agent-based models of geographical systems, 2012. New York, Springer, 253-269. DOI: 10.1007/97890-481-8927-4 13.

8. Matthews, R.B., Gilbert, N.G., Roach, A., Polhill, J.G., Gotts, N.M. Agent-based land-use models: a review of applications. Landscape Ecology, 2007, vol. 22, pp. 1447-1459. DOI: 10.1007/s10980-007-9135-1.

9. Crooks, A.T., Heppenstall A.J., Malleson N., Manley E. Agent-based modeling and the city: a gallery of applications. In: Shi W., Goodchild M.F., Batty M., Kwan MP., Zhang A. (eds) Urban Informatics. Singapore, Springer, 2021. DOI: 10.1007/978-981-15-8983-6_46.

10. Huang, Q., Parker, D.C., Filatova, T., Sun, S. A review of urban residential choice models using agent-based modeling. Environment and Planning B: Urban Analytics and City Science, 2013, vol. 41, no. 4, pp. 661-689. DOI: 10.1068/b120043p.

11. Kagho, G.O., Balac, M., Axhausen, K.W. Agent-based models in transport planning: current state, issues, and expectations. Procedia Computer Science, 2020, vol. 170, pp. 726-732. DOI: 10.1016/j. procs.2020.03.164.

12. Davidsson P. et al. Agent-based spproaches to transport logistics. In: Klügl F., Bazzan A., Ossowski S. (eds) Applications of Agent Technology in Traffic and Transportation. Basel, Birkhäuser, 2005. pp 1-15. DOI: 10.1016/j.trc.2005.07.002.

13. An, L. Modeling human decisions in coupled human and natural systems: Review of agent-based models. Ecological Modelling, 2012, vol. 229, pp. 25-36. DOI: 10.1016/j.ecolmodel.2011.07.010.

14. Heckbert, S., Baynes, T., Reeson, A. Agent-based modeling in ecological economics. Ecological Economics Reviews, 2010, vol. 1185, pp. 39-53. DOI: 10.1111/j.1749-6632.2009.05286.x.

15. Alam, S.J., Geller, A. Networks in agent-based social simulation. In: A.J. Heppenstall, A.T. Crooks, L.M. See, \& M. Batty (eds.) Agent-based models of geographical systems, 2012. Netherlands: Springer. 199-216. DOI: 10.1007/978-90-481-8927-4_11.

16. Rand, W., Rust, R.T. Agent-based modeling in marketing: guidelines for rigor. International Journal of Research in Marketing, 2011, vol. 28, no. 3, pp. 181-193. DOI: 10.1016/j.jiresmar.2011.04.002. 
17. Squazzoni, F. Agent-Based Computational Sociology. Wiley, 2012. 238 p. DOI: $10.1002 / 9781119954200$.

18. Filatova, T., Verburg, P.H., Parker, D.C., Stannard, C.A. Spatial agent-based models for socio-ecological systems: challenges and prospects. Environmental modelling \& software, 2013, vol. 45, pp. 1-7. DOI: 10.1016/j.envsoft.2013.03.017.

19. Heppenstall, A., et al. Future developments in geographical agent-based models: challenges and opportunities. Geographical Analysis, 2021, vol. 53, pp. 76-91. DOI: 10.1111/gean.12267.

20. Suslov V. I., Domozhirov D. A., Ibragimov N. M., Kostin V. S., Melnikova L. V., Tsyplakov A. A. Agent-orientirovannaya mnogoregio-nal'naya model' «zatraty - vypusk» rossiyskoy ekonomiki [AgentBased Multiregional Input-Output Model of the Russian Economy] // Ekonomika i matematicheskie metody [Economics and Mathematical Methods]. 2016, Vol. 52, No. 1, Pp. 112-131. (In Russ.).

21. Domozhirov D. A., Ibragimov N. M., Melnikova L. V., Tsyplakov A. A. Intgratsiya podkhoda "zatraty-vypusk" v agentno-orientirovannoe modelirovanie: Metodologicheskiye osnovy [Integration of Input-Output Approach into Agent-Based Modeling. Part 1. Methodological Principles] // Mir ekonomiki i upravleniya [World of Economics and Management]. 2017, Vol. 17, No. 1, Pp. 86-99. (In Russ.).

22. Epstein, J., Axtell, R. Growing Artificial Societies: Social Science from the Bottom Up. Brookings Institution Press and MIT press, 1996. 228 p. DOI: 10.7551/mitpress/3374.001.0001.

23. Gallegati, M., Kirman, A. Reconstructing economics: agent-based models and complexity. Complexity Economics, 2012, vol. 1, pp. 5-31. DOI: 10.7564/12-COEC2.

24. Franklin, S., Graesser, A. Is it an agent, or just a program? In: Mueller, J.P., Wooldridge, M.J., Jennings, N.R. (Eds.), Intelligent Agents III, 1997, Springer, Berlin, 21-36. DOI: 10.1007/BFb0013570.

25. Epstein, J.M. Generative Social Science: Studies in agent-based computational modeling. Princeton, Princeton University Press, 2006. 356 p. DOI: 10.1515/9781400842872.

26. Macal, C., North, M. Tutorial on agent-based modelling and simulation. Journal of Simulation, 2010, vol. 4, pp. 151-162. DOI: 10.1057/jos.2010.3.

27. Crooks A.T., Heppenstall A.J. Introduction to agent-based modelling. In Agent-based Models of Geographical Systems, 2012, Eds.: A.J. Heppenstall, A.T. Crooks, L.M. See, M. Batty. Springer, Dordrecht. pp. 85-105. DOI: 10.1007/978-90-481-8927-4 5.

28. Bonabeau, E. Agent-based modeling: methods and techniques for simulating human systems. Proceedings of the National Academy of Sciences, 2002, vol. 99 (suppl 3), pp. 7280-7287. DOI: 10.1073/ pnas.082080899.

29. Axtell, R. Why agents? On the varied motivations for agent computing in the social sciences Washington, The Brookings Institution, Center on Social and Economic Dynamics, 22 p. (CSED Working Paper, n 17, 2000). Available at: https://www.brookings.edu/research/why-agents-on-the-varied-motivations-for-agent-computing-in-the-social-sciences/ (accessed 01.06.2021).

30. Borrill, P.L., Tesfatsion, L. Agent-based modeling: the right mathematics for the social sciences? The Elgar Companion to Recent Economic Methodology, 2011. New York: Edward Elgar Publishers, 228-258. DOI: $10.4337 / 9780857938077.00018$.

31. Ballot, G., Mandel, A., Vignes, A. Agent-based modeling and economic theory: where do we stand? Journal of Economic Interaction and Coordination, 2015, vol. 10, pp. 200-220. DOI: 10.1007/s11403-014-0132-6.

32. Gilbert, N. Agent-Based Models, 2nd ed. SAGE Publications, 2020. 128 p. DOI: $10.4135 / 9781506355580$.

33. Combes, P.-P., Mayer, T., Thisse, J.-F. Economic Geography: The Integration of Regions and Nations. Princeton, Princeton University Press, 2008. 416 p.

34. Batty M., Crooks A.T., See L.M., Heppenstall A.J. Perspectives on agent-based models and geographical systems. In Agent-based Models of Geographical Systems, 2012, Eds.: A.J. Heppenstall, A.T. Crooks, L.M. See, M. Batty. Springer, Dordrecht. pp. 1-15. DOI: 10.1007/978-90-481-8927-4_1.

35. Haase, D., Lautenbach, S., Seppelt, R. Modeling and simulating residential mobility in a shrinking city using an agent-based approach. Environmental Modeling and Software, 2010, vol. 25, pp. 1225-1240. DOI: 10.1016/j.envsoft.2010.04.009. 
36. Fattakhov, M.P. Agento-orientirovannaya model' sotsialno-economicheskogo razvitiya Moskvy [An Agent-Based Model of Socio-Economic Development of Moscow] // Ekonomika i matematicheskie metody [Economics and Mathematical Methods]. 2013. Vol. 49, No. 2, Pp. 30-42. (In Russ.).

37. Manson, S.M., Sun, S., Bonsal, D. Agent-based modeling and complexity. In: Agent-based Models of Geographical Systems, 2012, Eds.: A.J. Heppenstall, A.T. Crooks, L.M. See, M. Batty. Springer, Dordrecht. pp. 125-139. DOI: 10.1007/978-90-481-8927-4_7.

38. Fowler, C.S. Finding equilibrium: how important is general equilibrium to the results of geographical economics? Journal of Economic Geography, 2011, vol. 11, no. 3, pp. 457-480. DOI: 10.1093/jeg/lbq006.

39. Filatova, T. Empirical agent-based land market: integrating adaptive economic behavior in urban land-use models. Computers, Environment and Urban Systems, 2015, vol. 54, pp. 397-413. DOI: 10.1016/j. compenvurbsys.2014.06.007.

40. Furtado, B.A. Policy space: agent-based modeling. Rio de Janeiro, Ipea, 2018. $121 \mathrm{p}$.

41. Chen, S.-H. Agent-Based Computational Economics: how the idea originated and where it is going. Routledge, 2016. 528 p.

42. Sakoda, J. M. The checkerboard model of social interaction. Journal of Mathematical Sociology, 1971, vol. 1, pp. 119-132. DOI: 10.1080/0022250X.1971.9989791.

43. Zhang, L., Levinson, D., Zhu, S. Agent-based model of price competition, capacity choice, and product differentiation on congested networks. Journal of Transport Economics and Policy, 2008, vol. 42, no. 3, pp. 435-461.

44. Aziz, H.A. et al. A high resolution agent-based model to support walk-bicycle infrastructure investment decisions: a case study with New York City. Transportation Research Part C: Emerging Technologies, 2018, vol. 86, pp. 280-299. DOI: 10.1016/j.trc.2017.11.008.

45. Heckbert, S. Agent-based modelling of emissions trading for coastal landscapes in transition. Journal of Land Use Science, 2011, vol. 6, no. 2-3, pp. 137-150. DOI: 10.1080/1747423X.2011.558599.

46. Birkin, M, Heppenstall, A. Extending spatial interaction models with agents for understanding relationships in a dynamic retail market. Urban Studies Research, 2011, vol. 2011, article ID 403969, 12 p. DOI: $10.1155 / 2011 / 403969$.

47. Sturley, C., Newing, A., Heppenstall A. Evaluating the potential of agent-based modelling to capture consumer grocery retail store choice behaviours. The International Review of Retail, Distribution and Consumer Research, 2018, vol. 28, no. 1, pp. 27-46. DOI: 10.1080/09593969.2017.1397046.

48. Balać, M., Ciari, F. Retailers location choice based on shopping and land prices. In 21st International Conference on Recent Advances in Retailing and Services Science, 2014 (EIRASS 2014). IVT, ETH Zurich. DOI: 10.3929/ethz-b-000081073.

49. Tsyplakov, A.A., Melnikova, L.V. Investitsii v osnovnoy kapital i makroeconomicheskoye agent-orientirovannoye modelirovaniye [Fixed Investments and Macroeconomic Agent-Based Modeling]. // Mir ekonomiki i upravleniya [World of Economics and Management]. 2021. T. 21, № 1. C. 5-25 . . 2021. Vol. 21, No. 1, Pp. 5-25. (In Russ.)] / DOI: 10.25205/2542-0429-2021-21-1-5-28.

50. Dawid, H., Harting, P., van der Hoog, S., Neugart, M. Macroeconomics with heterogeneous agent models: fostering transparency, reproducibility and replication. Journal of Evolutionary Economics, 2019, vol. 29, pp. 467-538. DOI: 10.1007/s00191-018-0594-0.

51. Petrović, M. et al. Eurace Open: an agent-based multi-country model. Universitat Jaume I, Working Papers, vol. 9, 2017.

52. Caiani, A., Catullo, E., Gallegati, M. The effects of fiscal targets in a monetary union: a multi-country agent-based stock flow consistent model. Industrial and Corporate Change, 2018, vol. 27, no. 6, pp. 1123-1154. DOI: $10.1093 /$ icc/dty016.

53. Dosi, G., Roventini, A. Russo, E. Endogenous growth and global divergence in a multi-country agent-based model. Journal of Economic Dynamics and Control, 2019, vol. 101, pp. 101-129. DOI: 10.1016/j. jedc.2019.02.005. 